\title{
Sistem Pemantauan Kadar Gas pada Tambang Batu bara Berbasis IoT Menggunakan Teknologi Komunikasi LoRa
}

\author{
Fauzi Muhammad Ikhsan, dan Muhammad Rivai \\ Departemen Teknik Elektro, Institut Teknologi Sepuluh Nopember (ITS) \\ e-mail:muhammad_rivai@ee.its.ac.id
}

\begin{abstract}
Abstrak - Sistem pemantauan kadar gas pada tambang batu bara berbasis IoT menggunakan teknologi komunikasi LoRa adalah sebuah sistem portabel yang berfungsi untuk memantau kadar gas yang berbahaya di tambang menggunakan dua sensor dan modul GPS untuk mengetahui posisi dari alat ini, serta menggunakan LoRa sebagai modul komunikasi. Pembuatan alat ini didasarkan oleh adanya gas yang berbahaya untuk manusia di daerah pertambangan, dari segi kecelakaan kerja seperti kebakaran atau ledakan yang dikarenakan gas $\mathrm{CH}_{4}$ dan juga sistem pernapasan yang akan terganggu jika terlalu banyak terpapar gas $\mathrm{CO}_{2}$. Sistem ini dapat memantau perubahan konsentrasi gas. Sensor yang digunakan adalah sensor gas jenis MQ-02 dan MQ-135. Dalam penelitian ini mengimplementasikan sistem IoT untuk pemantauan kadar gas di tambang batu bara. Alat ini nantinya dapat dibawa oleh pengguna asalkan masih dalam jarak yang stabil untuk komunikasi antar LoRa. Ketika LoRa di transmitter mengirimkan data, maka LoRa di receiver akan menerima data tersebut dan mengolahnya. Data kemudian dikirim melalui komunikasi serial ke NodeMCU, dan diteruskan ke aplikasi yang ada di smart phone. Pengujian sensor gas dilakukan dengan beberapa bahan seperti asap dari kertas dan asap rokok. Hasil yang didapatkan di pengujian tersebut berbeda. Jarak komunikasi maksimal yang bisa dilakukan di daerah perkotaan kurang lebih 600 meter. Konsentrasi gas yang terukur saat pengujian relatif naik turun dikarenakan faktor alam seperti adanya angin.
\end{abstract}

Kata Kunci-Arduino, IoT, Konsentrasi Gas, LoRa, Tambang Batubara.

\section{PENDAHULUAN}

$\mathrm{P}$ ERTAMBANGAN adalah cara untuk mengambil mineral dan sumber energi yang tersimpan di bawah tanah yang kita pijak ini. Seperti batu bara, minyak, emas, kapur, dan sejenisnya. Saat ini, industri pertambangan mineral dan sumber energi sudah dilakukan hampir di seluruh dunia. Di masa lalu, ada orang yang dikirim untuk mengecek kondisi tambang di beberapa bagian. Mereka memiliki tugas untuk melaporkan kondisi tambang dengan waktu nyata. Metode ini sangat membuang- buang waktu dan tidak efektif [1].

Untuk tujuan memperbaiki sistem komunikasi yang ada di daerah tambang, dan untuk mencapai keinginan dalam mobilitas tinggi serta keefektifan waktu, dibutuhkan sebuah sistem yang mendukung. Sistem pemantau yang berbasis IoT dapat membantu untuk mengirim data kondisi tambang secara waktu nyata [1].
Tabel 1.

Komposisi udara bersih di atmosfer

\begin{tabular}{l|cc}
\multicolumn{3}{c}{ Komposisi udara bersih di atmosfer } \\
\cline { 2 - 3 } \multicolumn{1}{c}{ Gas } & \multicolumn{2}{c}{ Konsentrasi } \\
\hline Nitrogen & Volume (\%) & PPM \\
Oksigen & 78,08 & 780,840 \\
Argon & 20,95 & 209,460 \\
Karbon dioksida & 0,934 & 9,340 \\
Neon & 0,033 & 330 \\
Helium & 0,00180 & 18 \\
Metana & 0,00050 & 5 \\
Kripton & 0,00020 & 2 \\
\hline \hline
\end{tabular}

Tabel 2.

Kadar gas pada area tambang batu bara

\begin{tabular}{cc}
\hline \hline $\mathrm{Gas}$ & Ambang batas \\
\hline $\mathrm{O}_{2}$ & Konsentrasi minimum $19.5 \%$ \\
$\mathrm{CH}_{4}$ & Konsentrasi maksimum $5000 \mathrm{ppm}$ \\
$\mathrm{CO}_{2}$ & Konsentrasi maksimum $5000 \mathrm{ppm}$ \\
$\mathrm{CO}$ & Konsentrasi maksimum $25 \mathrm{ppm}$ \\
\hline \hline
\end{tabular}

Kondisi tambang batu bara yang diobservasi antara lain adalah kadar karbon dioksida dan kadar gas metana. Di bagian sensor terdiri atas sensor gas $\mathrm{CO}_{2}$ (MQ-135), dan sensor gas $\mathrm{CH}_{4}$ (MQ-2). Sensor- sensor tersebut telah disesuaikan dengan kondisi kadar gas yang ada di tambang [2].

Saat ini sistem yang diperlukan adalah sistem wireless sensor network, dimana sistem ini mempunyai volume kecil dan ringan. Dengan keuntungan tersebut, lokasi dari wireless node dapat berpindah-pindah dan dapat dilepas maupun dipasang seperlunya. Wireless node ini mengungguli sistem komunikasi yang masih menggunakan kabel dan bisa dipasang di daerah yang tidak ada manusia. Dalam suatu kasus ketika jalur komunikasi terputus karena suatu masalah, wireless node tersebut tetap dapat melakukan komunikasi dan menyampaikan informasi [3].

Sistem ini sendiri di bagian processing memakai sebuah mikrokontroler. Untuk sistem komunikasi antara node dengan receiver memakai modul LoRa. Modul LoRa dikondisikan untuk menerima informasi dari node dan mengirim informasi tersebut ke LoRa lainnya untuk dikirim ke receiver yang selanjutnya akan dipublish ke sebuah aplikasi dengan menggunakan bantuan NodeMCU. Hasil yang diharapkan adalah alat ini dapat membantu mengurangi tingkat kecelakaan atau kematian di daerah pertambangan [4]. 


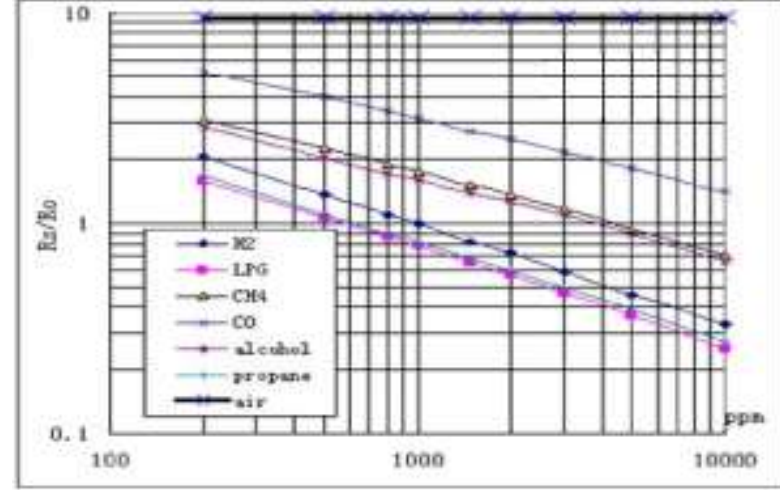

Gambar 1. Kurva karakteristik sensitivitas MQ-02.

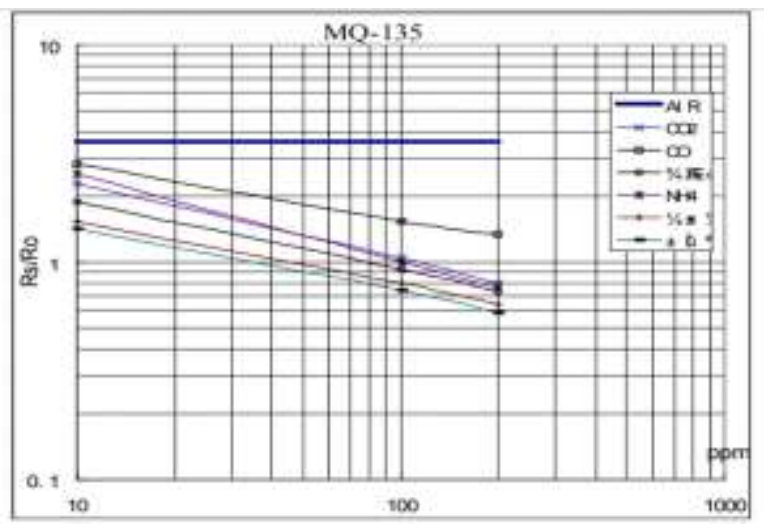

Gambar 2. Kurva karakteristik sensitivitas MQ-135.

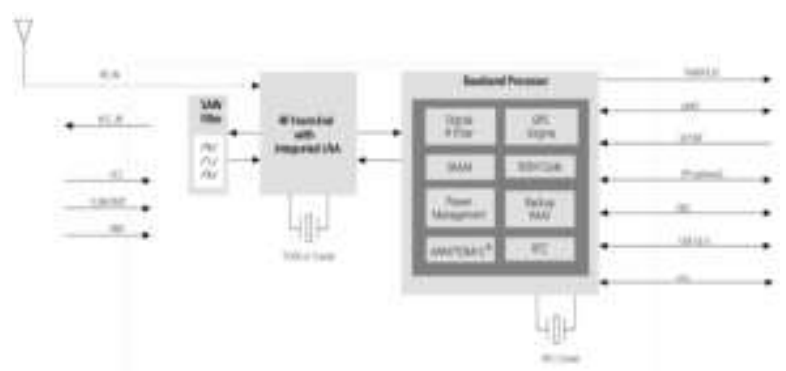

Gambar 3. Blok diagram modul NEO-6M.

\section{II.TINJAUAN PUSTAKA}

\section{A. Kandungan Gas pada Tambang Batubara}

Di area pertambangan, persentase dari oksigen akan berkurang dalam suatu proses yang dikenal sebagai pengenceran oleh mesin pembakaran, api dan pembakaran kayu suhu rendah, yang dalam proses tersebut menambahkan gas-gas lain seperti karbon monoksida dan karbon dioksida. Salah satu gas yang berbahaya lainnya dalam pertambangan adalah metana. Gas metana biasanya ada karena terlepas dari fraktur material saat penambangan berlangsung. Dengan kondisi tertentu, konsentrasi gas metana dapat menciptakan ledakan ketika berada di antara 5\% sampai $15 \%$. Ketika konsentrasinya sudah melebihi $15 \%$ maka yang terjadi hanyalah adanya kebakaran tanpa ledakan. Dan di bawah 5\% maka tidak akan terjadi kebakaran atau ledakan. Tabel 1 menunjukkan komposisi udara yang ada di atmosfer kita. Tabel 2 adalah gas yang ada di area pertambangan beserta batas kadar gas tersebut.

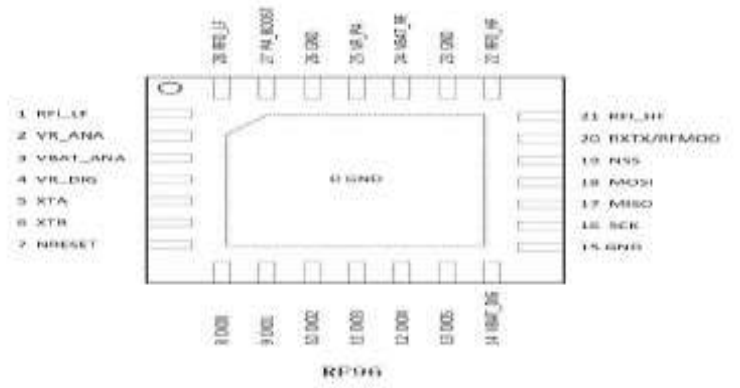

Gambar 4. Pin diagram RF96.

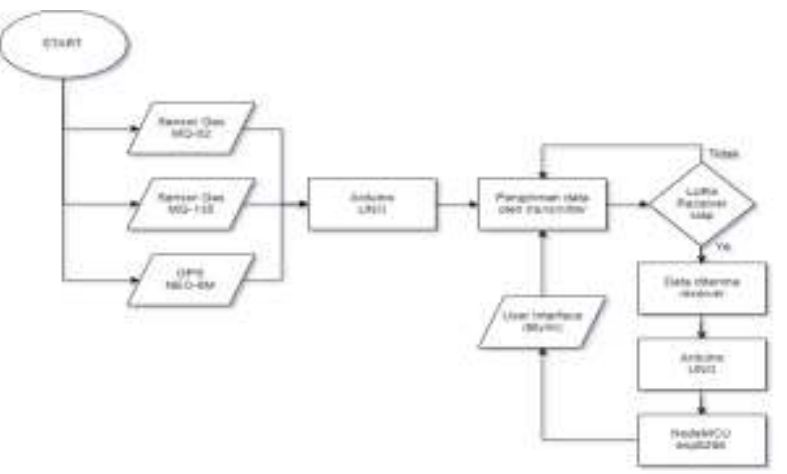

Gambar 5. Flowchart sistem pemantauan.

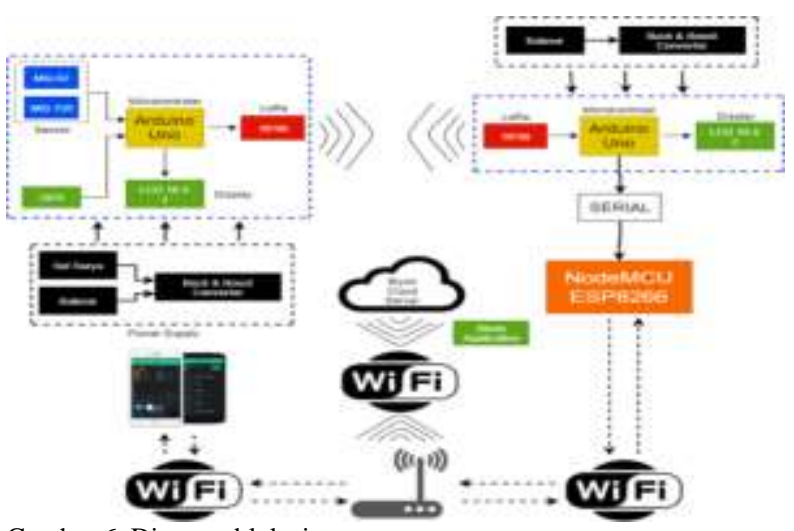

Gambar 6. Diagram blok sistem.

\section{B. Sensor Gas MQ-02}

Bahan utama dari sensor ini adalah $\mathrm{SnO}_{2}$ dengan konduktivitas rendah pada udara bersih. Jika terdapat kebocoran gas, konduktivitas sensor menjadi lebih tinggi. Setiap kenaikan konsentrasi gas maka konduktivitas sensor juga naik. MQ-2 sensitif terhadap gas LPG, Propana, Hidrogen, Karbon Monoksida, Metana dan Alkohol serta gas mudah terbakar di udara lainnya. Sensor gas dan asap ini mendeteksi konsentrasi gas yang mudah terbakar di udara serta asap dan output membaca sebagai tegangan analog. Sensor dapat mengukur konsentrasi gas mudah terbakar dari 300 sampai 10.000 sensor ppm, dapat beroperasi pada suhu dari -20 sampai $50^{\circ} \mathrm{C}$ dan mengkonsumsi kurang dari $150 \mathrm{~mA}$ pada 5V [5]. Gambar 1 merupakan karakteristik sensitivitas sensor gas MQ02 terhadap gas yang dapat dideteksi. Sumbu $\mathrm{X}$ menandakan konsentrasi gas, sumbu Y menandakan rasio resistensi dari sensor (Rs/Ro). Dimana Rs adalah resistensi dari berbagai macam gas, sementara Ro adalah resistensi sensor dalam 1000ppm Hydrogen [6]. Kalibrasi sensor gas agar didapatkan 
Tabel 3.

Pengujian sensor terhadap udara bersih

\begin{tabular}{c|cc}
\hline \hline \multirow{2}{*}{ Waktu (s) } & \multicolumn{2}{c}{ Konsentrasi Gas (PPM) } \\
\cline { 2 - 3 } & MQ-02 & MQ-135 \\
\hline 0 & 2,78 & 399,51 \\
8 & 2,74 & 396,20 \\
16 & 2,64 & 394,02 \\
24 & 2,61 & 398,96 \\
32 & 2,62 & 396,20 \\
40 & 2,57 & 395,66 \\
48 & 2,61 & 395,11 \\
56 & 2,60 & 361,85 \\
64 & 2,57 & 386,50 \\
72 & 2,59 & 381,77 \\
80 & 2,62 & 375,57 \\
\hline \hline
\end{tabular}

Tabel 4.

Pengujian sensor terhadap asap rokok

\begin{tabular}{c|cc}
\hline \hline \multirow{2}{*}{ Waktu (s) } & \multicolumn{2}{|c}{ Konsentrasi Gas (PPM) } \\
\cline { 2 - 3 } & MQ-02 & MQ-135 \\
\hline 0 & 1,85 & 397,90 \\
8 & 1,82 & 2788,26 \\
16 & 1,83 & 8180,23 \\
24 & 1,83 & 3061,75 \\
32 & 1.84 & 2773,59 \\
40 & 1,84 & 8641,89 \\
48 & 1,84 & 8273,45 \\
56 & 1,83 & 9361,80 \\
64 & 1,82 & 4243,80 \\
72 & 1,82 & 8027,94 \\
80 & 1,83 & 8631,76 \\
\hline \hline
\end{tabular}

Tabel 5.

Pengujian sensor terhadap asap kertas

\begin{tabular}{c|cc}
\hline \hline \multirow{2}{*}{ Waktu (s) } & \multicolumn{2}{|c}{ Konsentrasi Gas (PPM) } \\
\cline { 2 - 3 } & MQ-02 & MQ-135 \\
\hline 0 & 4,28 & 662,79 \\
8 & 3,69 & 578,34 \\
16 & 3,46 & 3087,70 \\
24 & 3,45 & 926,01 \\
32 & 3,45 & 755,36 \\
40 & 3,45 & 2598,61 \\
48 & 3,44 & 3235,56 \\
56 & 3,45 & 1220,46 \\
64 & 3,45 & 1486,26 \\
72 & 3,45 & 3244,55 \\
80 & 3,45 & 4902,44 \\
\hline \hline
\end{tabular}

nilai ppm dari gas yang diinginkan yaitu dengan melakukan analisa dari kurva karakteristik sensitivitas dari sensor dan menggunakan rumus power function dengan persamaan (1), sehingga didapatkan persamaan (2) untuk mendapatkan nilai ppm dari gas yang diukur.

$$
\begin{aligned}
& y=a \cdot x^{b} \\
& \text { jadi, } \\
& \text { ppm }=a \cdot(R s / R o)^{b}
\end{aligned}
$$

Dengan menggunakan power regression maka didapatkan scaling factor (a), dan exponent (b), untuk gas yang akan diukur. Lalu menggunakan persamaan (3) untuk mendapatkan nilai Ro.

$$
R o=R \operatorname{sqs} \operatorname{sqr}(a / p p m, b)=R \operatorname{sexp}(\ln (a / p p m) / b)
$$

Tabel 6.

Pengujian sensor terhadap asap kerta.

\begin{tabular}{cc}
\hline \hline Volume $(\mathrm{mL})$ & $\mathrm{CO}_{2}(\mathrm{PPM})$ \\
\hline 1 & 791,39 \\
2 & 1047,65 \\
3 & 1165,79 \\
4 & 1270,81 \\
5 & 2605,32 \\
6 & 2940,79 \\
7 & 4098,41 \\
8 & 5401,81 \\
9 & 6670,25 \\
10 & 9648,77 \\
\hline \hline
\end{tabular}

Tabel 7.

Pengujian sensor terhadap asap batubara.

\begin{tabular}{cc}
\hline \hline Volume $(\mathrm{mL})$ & $\mathrm{CH}_{4}(\mathrm{PPM})$ \\
\hline 1 & 0,59 \\
2 & 0,68 \\
3 & 0,85 \\
4 & 0,96 \\
5 & 1,00 \\
6 & 1,14 \\
7 & 1,30 \\
8 & 1,77 \\
9 & 2,97 \\
10 & 3,05 \\
\hline \hline
\end{tabular}

\begin{tabular}{ccccc}
\hline \hline \multicolumn{5}{c}{$\begin{array}{c}\text { Tabel 8. } \\
\text { Pengujian LoRa }\end{array}$} \\
\hline \hline \multirow{2}{*}{ Jarak (m) } & \multicolumn{3}{c}{ Data Terkirim } & \multicolumn{2}{c}{ Data Diterima } \\
& MQ-02 & MQ-135 & MQ-02 & MQ-135 \\
\hline 100 & 0,91 & 361,64 & 0,91 & 361,64 \\
200 & 0,91 & 360,18 & 0,91 & 360,18 \\
300 & 0,91 & 309,91 & 0,91 & 309,91 \\
400 & 0,91 & 297,6 & 0,91 & 297,6 \\
500 & 0,91 & 348,38 & 0,91 & 348,38 \\
600 & 0,91 & 321,66 & 0,91 & 321,66 \\
\hline \hline
\end{tabular}

Untuk nilai Rs dapat diperoleh melalui website resmi dari BMKG untuk konsentrasi gas $\mathrm{CH}_{4}$ dan $\mathrm{CO}_{2}$ di udara saat ini.

\section{Sensor Gas MQ-135}

Sensor MQ-135 merupakan sebuah modul sensor yang dapat digunakan untuk menentukan kadar konsentrasi gas-gas berbahaya dalam udara. Modul ini dapat mendeteksi gas $\mathrm{CO}_{2}$, gas amonia, bensol, alkohol, serta gas berbahaya lainnya. Modul ini cocok digunakan pada proses penentuan kualitas udara (air quality control). Sensor dengan seri MQ ini digunakan karena sensor jenis ini hemat biaya dan mudah tersedia di pasaran. Sensor MQ-135 membutuhkan waktu pemanasan lebih sedikit, memberikan respon cepat dan sensitivitasnya baik [7].Prinsip kerja dari sensor ini adalah ketika timah dioksida (partikel semikonduktor) dipanaskan di udara pada suhu tinggi, oksigen diserap di permukaan. Di udara bersih, elektron donor dalam timah dioksida tertarik ke arah oksigen yang diserap pada permukaan bahan sensor. Ini mencegah aliran arus listrik. Dengan adanya gas pereduksi, kerapatan permukaan oksigen yang teradsorpsi berkurang karena bereaksi dengan gas pereduksi. Elektron kemudian dilepaskan ke dalam timah dioksida, yang memungkinkan arus mengalir bebas melalui sensor [8]. Gambar 2 merupakan karakteristik sensitivitas sensor gas MQ-135 terhadap gas yang dapat dideteksi. 


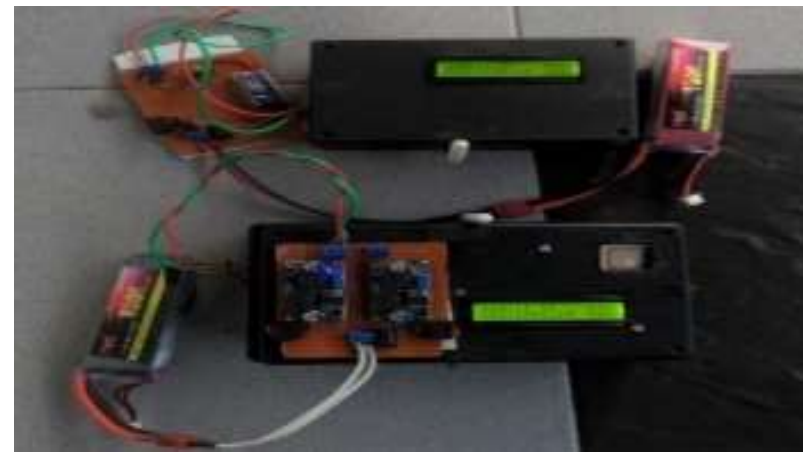

Gambar 7. Sistem secara keseluruhan untuk pengujian.

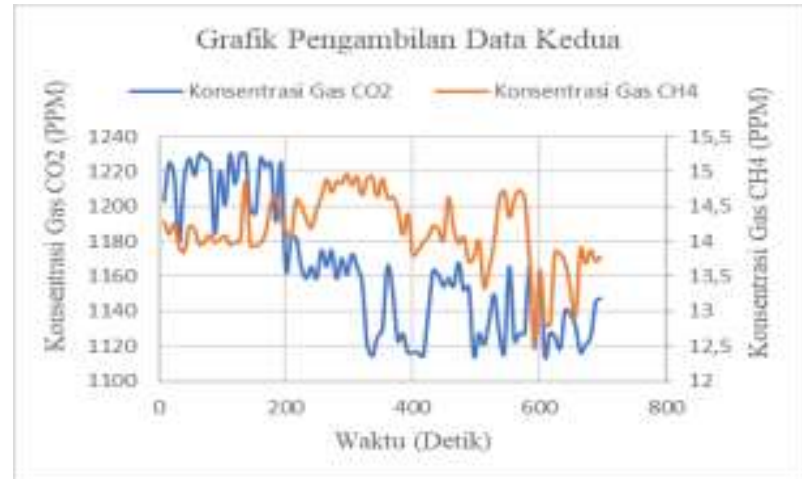

Gambar 8. Grafik pengambilan data.

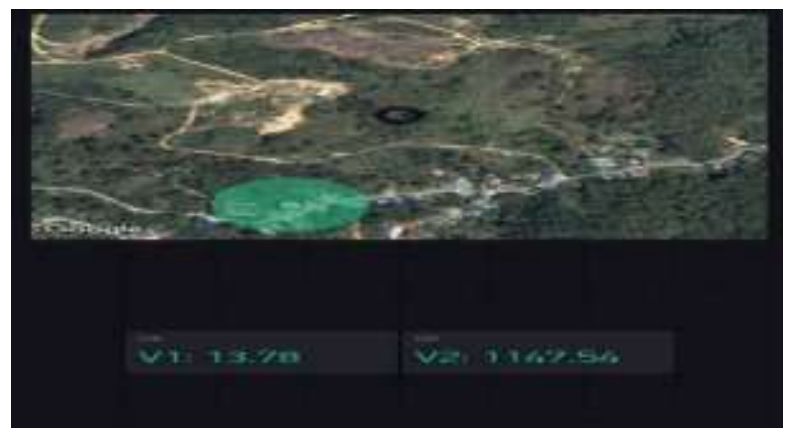

Gambar 9. Tampilan pengambilan data pada aplikasi Blynk.

\section{GPS u-Blox NEO-6M}

Modul GPS dengan jenis NEO-6M berukuran ringkas ini (25x35mm untuk modul, 25x25mm untuk antena) berfungsi sebagai penerima GPS yang dapat mendeteksi lokasi dengan menangkap dan memproses sinyal dari satelit navigasi. Jenis GPS ini cukup dapat diandalkan karena memiliki keakuratan yang cukup baik dan juga beberapa fitur yang cukup menguntungkan di antaranya terdapat baterai cadangan data, built-in elektronik kompas, dan built-in antena keramik untuk menangkap sinyal dengan kuat. Sistem posisi u-Blox 6 yang memiliki 50 kanal menawarkan Time-To-First-Fix (TTFF) dalam waktu di bawah 1 detik. Di mesin akuisisi, dengan 2 juta korelator, mampu melakukan pencarian waktu/frekuensi ruang paralel yang masif, memungkinkannya menemukan satelit secara instan [9]. Untuk blok diagram dari Modul NEO-6M dapat dilihat pada Gambar 3.

\section{E. LoRa RF96}

RF96 menggabungkan modem LoRa spread spectrum yang mana mampu mencapai jangkauan cukup jauh secara signifikan dari sistem yang ada berdasarkan modulasi FSK atau OOK. LoRa juga memberikan keuntungan yang signifikan pada selektivitas dan kinerja pemblokiran gangguan, lebih lanjut dapat meningkatkan keandalan dalam komunikasi tanpa kabel [10]. Pengguna dapat menentukan penyebaran spektrum pada modulasi bandwidth (BW), faktor penyebaran (SF) dan tingkat koreksi kesalahan (CR). Standar modulasi GFSK, FSK, OOK, dan GMSK juga disediakan untuk memungkinkan terjadinya kompatibilitas dengan sistem yang telah ada atau standar yang sudah ada seperti MBUS nirkabel dan IEEE 802.15.4g [11]. Untuk pin diagram dari LoRa RF96 dapat dilihat pada Gambar 4.

\section{F. LoRa RF96}

NodeMCU merupakan sebuah Firmware Open-Source dan Development Kit yang dapat membantu membangun produk berbasis IoT. NodeMCU dikembangkan untuk mempermudah Penggunaan API (Application Programming Interface) yang canggih untuk perangkat keras IO. API dapat mengurangi pekerjaan berlebih untuk mengkonfigurasi dan memanipulasi perangkat keras. NodeMCU dirancang memiliki Input dan Output seperti perangkat keras Arduino (IO) [12], [13].NodeMCU menggunakan MCU Wi-Fi dengan biaya terendah yaitu ESP 8266. ESP8266 Merupakan Chip Wi-Fi paling terintegrasi. Ukuran Chip adalah $5 \mathrm{~mm} \times 5 \mathrm{~mm}$. ESP8266EX minimal membutuhkan rangkaian eksternal dan pengintegrasian 32-bit Tensilica MCU, standar antarmuka digital periferal, sakelar antena, balun R, Power Amplifier, penguat penerima dengan noise rendah, filter dan modul manajemen daya. Semua diintegrasikan dalam satu paket kecil [14].

\section{G.Blynk}

Blynk merupakan platform sebuah layanan server yang digunakan untuk mendukung project Internet of Things dengan aplikasi berbasis iOS dan Android yang dapat dikontrol dengan Arduino atau Raspberry $\mathrm{Pi}$ dengan menggunakan akses Internet. Blynk merupakan dasbor digital di mana aplikasi ini dapat membangun antarmuka grafis bagi pengguna dengan tombol hanya drag dan drop [15]. Blynk diciptakan dengan tujuan untuk control dan monitoring hardware secara jarak jauh menggunakan komunikasi data internet ataupun intranet (jaringan LAN). Kemampuan menyimpan data dan menampilkan data secara visual baik menggunakan angka, warna ataupun grafis semakin memudahkan dalam pembuatan project di bidang Internet of Things.

\section{PERANCAGAN SISTEM}

\section{A. Gambaran Umum}

Alat yang dirancang bertujuan untuk memonitor kadar gas di area tambang batu bara terutama kadar gas metana, dan gas karbon dioksida. Untuk flowchart dari sistem dapat dilihat pada Gambar 5. Perancangan alat berupa sebuah board yang berisi mikrokontroler Arduino Uno dilengkapi dengan dua sensor gas, modul GPS, LoRa (RF96), LCD display, NodeMCU, dan terminal catu daya. Sensor gas digunakan untuk mengetahui 
kadar gas di area tambang batu bara. Modul GPS akan mengambil data dari satelit untuk mengetahui lokasi dari alat ini dengan menunjukkan latitude dan longitude. LCD digunakan untuk menampilkan data yang didapatkan dari sensor. Mikrokontroler akan membaca data dari sensor-sensor yang terhubung, kemudian data tersebut akan dikirim dengan modul LoRa. Alat dilengkapi dengan sel surya sebagai sumber daya pada bagian kotak transmitter. Data yang dikirim akan diterima oleh mikrokontroler pada kotak receiver melalui modul LoRa. Selanjutnya data diolah dan diteruskan ke NodeMCU dan LCD display. Setelah data diterima oleh NodeMCU, selanjutnya data akan dikirim ke aplikasi Blynk di smartphone untuk memonitor kadar gas dan lokasi dari transmitter.

\section{B. Diagram Blok Sistem}

Sensor yang digunakan adalah sensor gas MQ-02 dan sensor gas MQ-135. Kedua sensor tersebut diletakkan pada kotak transmitter bersama dengan modul GPS, LCD, LoRa, serta terminal catu daya. Sensor MQ-02 digunakan untuk mengetahui kadar gas $\mathrm{CH}_{4}$, dan sensor MQ-135 digunakan untuk mengetahui kadar gas $\mathrm{CO}_{2}$. Sedangkan LoRa digunakan untuk mengirim data sensor yang telah didapat. Sensor gas MQ-02, MQ-135 dan modul GPS dibaca oleh mikrokontroler Arduino Uno setiap 8 detik sekali. Hasil pembacaan dari sensor ini akan dikirimkan dengan menggunakan modul LoRa. Selain itu akan ditampilkan pada LCD display. Data yang dikirim akan diterima dengan LoRa pada kotak receiver. Pada kotak receiver juga terdapat mikrokontroler Arduino Uno untuk mengolah data sensor yang diterima odari LoRa. Kemudian juga ada mikrokontroler NodeMCU ESP8266 untuk mengirimkan data yang diterima ke aplikasi Blynk di smartphone. Blok diagram dapat dilihat pada Gambar 6.

\section{PENGUJIAN DAN ANALISIS}

\section{A. Pengujian Sensor Gas}

Pengujian dilakukan dengan empat kondisi, yaitu kondisi pertama merupakan kondisi ketika udara bersih atau udara bebas, kondisi kedua ketika ada asap rokok, dan kondisi ketiga ketika ada asap kertas antara lain:

1) Pengujian Sensor Terhadap Udara Bersih

Pada pengujian ini dilakukan dengan udara yang ada pada sekitar lokasi uji. Pengujian dilakukan dengan tidak memperhitungkan adanya polusi yang ada pada lokasi uji. Data yang didapat cukup bervariasi. Hasil pengujian dapat dilihat pada Tabel 3.

\section{2) Pengujian Sensor Terhadap Asap Rokok}

Pada pengujian ini dilakukan dengan membakar rokok hingga menghasilkan asap. Pengujian ini tidak memperhitungkan kondisi yang dapat mengganggu pengujian, seperti angin, jarak antara asap dengan sensor, dan asap yang dikeluarkan oleh rokok juga bisa tidak stabil. Karena faktor tersebut data yang terbaca berubah-ubah tidak mengikuti perubahan volume asap. Hasil pengujian dapat dilihat pada Tabel 4.

\section{3) Pengujian Sensor Terhadap Asap Kertas}

Pada pengujian ini dilakukan dengan membakar kertas hingga menghasilkan asap. Pengujian ini tidak memperhitungkan kondisi yang dapat mengganggu pengujian, seperti angin, jarak antara asap dengan sensor, dan asap yang dikeluarkan oleh kertas juga bisa tidak stabil. Karena faktor tersebut data yang terbaca berubah-ubah tidak mengikuti perubahan volume asap. Hasil pengujian dapat dilihat pada Tabel 5.

\section{B. Pengujian Sensor Per Volume}

Pengujian sensor per volume antara lain: (1)Pengujian Sensor MQ-135. Pengujian ini dilakukan untuk mengetahui respon sensor terhadap volume asap yang diberikan. Asap yang digunakan adalah asap yang dihasilkan dari pembakaran kertas. Metode pengujian ini dilakukan dengan membakar kertas dan memasukkan asapnya ke dalam botol. Untuk mengambil asap digunakan tabung suntik yang ada ukuran volumenya, dan memiliki satuan ukuran mililiter.. Pengujian dilakukan dengan memberikan sensor asap yang telah diambil dari botol melalui tabung suntik. Hasil yang didapatkan setiap kenaikan satu mililiter volume, nilai ppm yang terbaca juga naik. Hasil pengujian dapat dilihat pada Tabel 6; (2)Pengujian Sensor MQ02. Pengujian ini dilakukan untuk mengetahui respon sensor terhadap volume asap yang diberikan. Asap yang digunakan adalah asap yang dihasilkan dari pembakaran batu bara. Metode pengujian ini dilakukan dengan membakar batu bara. Hasil pengujian dapat dilihat pada Tabel 7.Pengujian dilakukan dengan memberikan sensor asap yang telah diambil dari botol melalui tabung suntik. Hasil yang didapatkan setiap kenaikan satu mililiter volume, nilai ppm yang terbaca juga naik.

\section{Pengujian Lora}

Jarak terjauh untuk Receiver menerima data dari Transmitter adalah $600 \mathrm{~m}$. Ada beberapa faktor yang mempengaruhi, seperti interferensi objek yang menjadi penghalang, atau gangguan frekuensi dari sinyal yang ada pada daerah perkotaan. Untuk bentuk fisik dari alat sistem pemantauan dapat dilihat pada Gambar 7. Untuk data yang didapatkan dapat dilihat pada Tabel 8 .

\section{D.Pengujian Keseluruhan}

Pengujian alat secara keseluruhan dilakukan di Kabupaten Samboja, Kalimantan Timur, dengan mengambil tempat pengujian di area pertambangan. Pengujian dilakukan dengan menempatkan transmitter di area yang memiliki rata-rata batubara relatif sedikit. Sedangkan receiver diletakkan pada jarak sekitar $1 \mathrm{Km}$. Gambar 8 menunjukkan pengamatan dilakukan selama 696 detik. Hasil yang didapatkan adalah konsentrasi gas $\mathrm{CH}_{4}$ dan $\mathrm{CO}_{2}$ berubah-ubah namun perubahannya relatif rendah. Konsentrasi gas $\mathrm{CH}_{4}$ termasuk rendah dengan nilai tertinggi sebesar $14,96 \mathrm{ppm}$ dan nilai terendah sebesar 12,48 ppm. Konsentrasi gas $\mathrm{CO}_{2}$ juga masih termasuk rendah dengan nilai tertinggi sebesar $1230,32 \mathrm{ppm}$ dan nilai terendah sebesar $1134,34 \mathrm{ppm}$. Nilai konsentrasi $\mathrm{CO}_{2}$ yang relatif rendah disebabkan oleh penempatan transmitter dengan lokasi yang minim batu bara, sedangkan nilai konsntrasi 
gas $\mathrm{CH}_{4}$ yang rendah dikarenakan kualitas batu bara yang ada di lokasi tersebut termasuk buruk, atau bisa dikatakan tidak layak untuk diambil sebagai hasil tambang. Dengan jarak sejauh $1 \mathrm{Km}$ receiver masih bisa menerima data yang dikirim oleh transmitter dengan baik. Tampilan dari aplikasi Blynk berisi nilai konsentrasi gas yang diobservasi oleh sensor gas $\mathrm{CH}_{4}$ dan $\mathrm{CO}_{2}$ beserta tampilan dari google maps yang menunjukkan lokasi dari transmitter juga receiver seperti yang ditunjukkan pada Gambar 9.

\section{V.KESIMPULAN}

Pada penelitian ini telah dirancang dan dibuat sebuah sistem pemantauan kadar gas pada tambang batu bara berbasis IoT menggunakan teknologi komunikasi LoRa. Modul GPS dapat membaca lokasi dengan baik ketika berada di luar ruangan. LoRa dapat mengirimkan data dengan baik dalam jarak kurang lebih $600 \mathrm{~m}$ jika dicoba di area perkotaan, namun LoRa dapat mengirimkan data hingga $1,6 \mathrm{Km}$ di area pertambangan. Nilai rata-rata $\mathrm{CH}_{4}$ dan $\mathrm{CO}_{2}$ di area pertambangan adalah 18,72 ppm dan 2196,20 ppm. Dalam aplikasi Blynk, data yang diterima dari Node MCU belum bisa secara cepat sampai ke aplikasi dikarenakan ada faktor yang mempengaruhi, seperti jaringan seluler lemah, pengiriman data juga menjadi lemah.

\section{DAFTAR PUSTAKA}

G. L. Borhade, M. B. Kadu, and R. P. Labade, "GSM Operated Wireless Sensor Based Mine Security and Safety Approach," in Communication, Control and Automation, ICCUBEA 2017, 2017.

[2] S. Molina, I. Soto, and R. Carrasco, "“'Detection of Gases and Collapses in Underground Mines using WSN," in Proceedings of the IEEE International Conference on Industrial Technology, 2011, pp. 219-225.

[3] J. Wang and P. Wang, "Based on Wireless Sensor Network Coal Mine Gas Monitoring System," in Proceedings of the 2012 International Conference on Industrial Control and Electronics Engineering, ICICEE 2012, 2012, pp. 1291-1294.

[4] M. R. Hendrik Hermawan, "Sistem Pemantauan Gunung Berapi Berbasis IoT Menggunakan NodeMCU dan LoRa."

[5] L. A. Akbar and M. Rivai, "Rancang Bangun Sensor Node pada Wireless Sensor Network Menggunakan Deret Sensor Gas dan Jaringan Syaraf Tiruan untuk Mendeteksi Kebakaran Hutan," J. Tek. ITS, vol. 5, no. 2, pp. A192-A197, Sep. 2016.

[6] L. Hanwei Electronics Co., "Technical Data MQ-2 Gas Sensor," 2019. .

[7] V. A. Ravindra and S. M. Rajbhoj, "Identification of Toxic Gases Using Electronic Nose," in 2017 International Conference on Computing, Communication, Control and Automation, ICCUBEA 2017, 2017, pp. 1-5.

[8] Radi, M. Rivai, and M. H. Purnomo, “'“Study on Electronic-NoseBased Quality Monitoring System for Coffee Under Roasting," J. Circuits, Syst. Comput., vol. 25, no. 10, 2016.

[9] Z. Wei, Y. Song, H. Liu, Y. Sheng, and X. Wang, "The research and implementation of GPS intelligent transmission strategy based on onboard Android smartphones," in Proceedings of 2013 3rd International Conference on Computer Science and Network Technology, ICCSNT 2013, 2014, pp. 1230-1233.

[10] Radi, Murtiningrum, B. Purwantana, F. S. Muzdrikah, M. S. Nuha, and M. Rivai, "Design of Wireless Sensor Network (WSN) with RF Module for Smart Irrigation System in Large," 2018 Int. Conf. Comput. Eng. Netw. Intell. Multimedia, CENIM 2018 - Proceeding, no. May 2019, pp. 181-185, 2018.

[11] Hope Microelectronics Co., "Low Power Long Range Transceiver Module V1.0," vol. 98, p. 121, 2014.

[12] S. L. H. Siregar and M. Rivai, "Monitoring dan Kontrol Sistem Penyemprotan Air Untuk Budidaya Aeroponik Menggunakan
NodeMCU ESP8266," J. Tek. ITS, vol. 7, no. 2, 2019.

[13] M. Husni, D. O. Siahaan, H. T. Ciptaningtyas, H. Studiawan, and Y. P. Aliarham, "Liquid volume monitoring based on ultrasonic sensor and Arduino microcontroller," in IOP Conference Series: Materials Science and Engineering, 2016, vol. 128, no. 1.

[14] L. K. P. Saputra and Y. Lukito, "Implementation of Air Conditioning Control System Using REST Protocol Based on NodeMCU ESP8266," in Proceeding of 2017 International Conference on Smart Cities, Automation and Intelligent Computing Systems, ICONSONICS 2017, 2017, vol. 2018-Janua, pp. 126-130.

[15] N. A. Z. M. Noar and M. M. Kamal, "The Development of Smart Flood Monitoring System Using Ultrasonic Sensor with Blynk Applications," 2017 IEEE Int. Conf. Smart Instrumentation, Meas. Appl. ICSIMA 2017, vol. 2017-Novem, no. August, pp. 1-6, 2018. 